Journal Universitas Muhammadiyah Gresik Engineering, Social Science, and Health International Conference (UMGESHIC)

UMGCINMATIC : $1^{\text {st }}$ Rethinking Education during Covid-19 Era: Challange and Innovation

\title{
THE DEVELOPMENT OF THE PANCASILA POP UP BOOK BASED ON SOCIAL VALUES IN DAILY LIFE FOR FOURTH GRADE ELEMENTARY SCHOOL STUDENTS
}

\author{
Author \\ Husliyana Mei Zahrah"1, Nanang Khoirul Umam, M.Pd², Ismail Marzuki, S.Ag,. M.Pd ${ }^{3}$ \\ Elementary School Teacher Education Study Program, Faculty of Teacher Training and \\ Education, University of Muhammadiyah Gresik, Sumatra 101 GKB, Gresik 61121 \\ Email: meyzahrah8673@gmail.com ${ }^{1)}$, nanang.khu@umg.ac.id ${ }^{2)}$, \\ ismailmarzuki@umg.ac.id ${ }^{3}$ )
}

\begin{abstract}
Husliyana Mei Zahrah (NIM. 170404023) The Development of The Pancasila Pop Up Book Based on Social Values in Daily Life for Fourth Grade Elementary School Student (Guided by Nanang Khoirul Umam, M.Pd dan Ismail Marzuki, M.Pd). This study aims to develop the Pancasila pop up book, to find (1) the validation of the Pancasila pop up book, (2) the response of students to the Pancasila pop up book. This research is development research that uses a 4D development model, consisting of Definiton, Design, Development, dan Desseminate with researcher modifications. The subjects of this study were students of class IV MI Al-Islam 1 Pantenan, totaling 6 students of elementary school. The data collection instruments used were validation sheets and student response questionnaires. The results obtained are, 1) The Pancasila pop up book with $92,5 \%$ results, very valid. The Pancasila pop up book was categorized as very valid because the validator stated that the Pancasila pop up book was used with a few revisions, worthy of testing, 2) The Pancasila pop up book with 97,3\% results, was very good. The Pancasila pop up book is practicial and also effective to be used as a tool or learning resource for students in the learning process.
\end{abstract}

Keyword: 4D model, Pancasila Pop Up Book, Social Values 


\section{INTRODUCTION}

Education is one form of developing the potential of every human being in order to build a nation. This assumption is because education has a goal in developing the quality and potential of a person, so as to create human resources who are able to master in various fields. According to Kompri (2015), education is a conscious effort made by adults in carrying out selfdevelopment activities, which makes humans whole in accordance with predetermined goals. In addition, education also includes teaching or direction unconsciously by educators on the physical and spiritual development of students towards the creation of a superior personality. Pancasila is the material contained in the subject of Pancasila and Citizenship Education. Pancasila itself is a guideline for the life of the nation for all Indonesian people. Pancasila has five precepts which become the principles and values of the life of the nation and state, which reads in the one and only God, just and civilized humanity, Indonesian unity, democracy led by wisdom in deliberation/representation, and social justice for all Indonesian people. . Each of the Pancasila precepts has its own symbol and meaning, so that students are required to learn the symbols and meanings of the Pancasila precepts in order to be able to associate and tell the relationship between the Pancasila symbols and everyday life.

Based on the results of interviews with fourth grade teachers at MI Al-Islam 1 Pantenan, researchers got information that fourth grade students still have difficulty understanding the meaning of the Pancasila precepts symbol, students have difficulty distinguishing the application of one precepts from other precepts in everyday life, students often feel bored and tend not to be enthusiastic in participating in learning due to the limitations of interesting learning resources, students listen more to explanations from the teacher so that students' understanding of the material provided is less evenly distributed and they feel bored more quickly in participating in learning.

Students have certain levels, including low grade levels and high grade levels. The low class is children aged 6 to 8 years who are in grades 1,2, and 3 of elementary school, while the high class is children at the age of 9 to 12 years who are in grades 4,5 , and 6 of elementary school. In this high class age, which is included in the age that is not early anymore or can be called preadolescence, students increasingly want to know who they are and also the environment they live in, children are more independent in solving problems and become more critical of things around them. High grade students tend to be more bored when they listen to explanations more, they prefer new things when learning in class such as interesting learning resources to increase students' interest in learning.

In the learning process, it is necessary to have learning resources such as interesting supporting textbooks to be used as a companion to student textbooks. This companion textbook helps the teacher in conveying information on learning materials to students, so that the existence of a supporting textbook can attract the attention of students so as not to get bored during the learning process, besides that it can help students to understand the material being 
conveyed easier, and improve motivation to learn to students when doing learning in class. This supporting textbook includes learning resources that are used when learning at school as a new thing for students.

Learning resources generally have short-term and long-term risks in their use. The shortterm risk of using learning resources for students is that they have difficulty understanding the material because the material presented in the learning resource is less effective. While the longterm risk, students feel bored more quickly in using learning resources because learning resources are less attractive. Therefore, there is a need for new innovations in learning resources in the form of Pop up Books that have qualities such as in presenting material more effectively which only presents important points, so that students understand the material presented more quickly. Pop up Book also has a 3-dimensional structure that can be seen from various directions so that students do not feel bored quickly when using these learning resources.

Based on the results of the description of the background above, the researchers developed a Pop up Book for learning Pancasila. The development of learning resources in the form of accompanying textbooks was carried out by researchers with the aim of making it easier for teachers to convey material to students and also making it easier for students to understand the meaning of symbols and distinguish the application of Pancasila precepts in everyday life, as well as recognize the social values contained therein. In the principles of Pancasila. Therefore, the title of this research study is "Development of a Pancasila Pop up Book Based on Social Values in Daily Life for Fourth Grade Elementary School Students", with the hope of increasing students' interest in learning and helping make it easier for students to understand the material presented by the teacher.

\section{METHODS}

This research uses the type of research development or Research and Development (R\&D), development research is a research where the research develops a new product or refines an old product in order to produce the desired product. This research uses a 4D development model or can be called 4P by Thiagarajan, et al in (Trianto, 2015) which consists of a development stage, namely Definition, Design, Development, and Desseminate. But in this study the researcher only used 3 of the 4 stages of development, namely Definition, Design, and Development.

This research was conducted at MI Al-Islam 1 Pantenan, Kec. Panceng, Kab. Gresik, which was conducted offline in the even semester of the 2020-2021 academic year, on Friday 11 July 2021. The subject of this study was aimed at fourth grade students, with a total of 6 students consisting of 3 male students. And 3 female students. This research focuses on developing learning resources in the form of a companion textbook, namely the Pancasila Pop up Book based on social values in everyday life for fourth grade students at MI Al-Islam 1 Pantenan.

Data collection techniques used by researchers to obtain data from the use of Pop Up Books through validation of Pop Up Books and giving questionnaires to students, along with data 
collection techniques carried out by researchers, namely: 1) Validation of Pop Up Books, the method used in validation Pop Up Book, namely by providing and showing a 3-dimensional supporting textbook in the form of the Pancasila Pop Up Book that has been made by the researcher to the validator. Furthermore, the validator will assess and provide criticism and suggestions based on the validation sheet that has been prepared by the researcher as an assessment of the Pop up Book that has been developed. 2) Student Response Questionnaire, Questionnaire is used by researchers as a tool to determine student responses and responses to the Pancasila Pop up Book, questionnaires are given to students after carrying out the learning process. The process of giving the questionnaire is done by giving instructions or directions to students to fill out the questionnaire, in filling out the questionnaire a check mark $(\sqrt{ })$ is given in the column that has been provided. The column in the questionnaire contains information Strongly Agree, Agree, Disagre, Disagree, and Strongly Disagree.

At the data collection instrument stage, the researcher prepares a Pop Up Book validation sheet and a questionnaire sheet, the following is an explanation of the data collection instrument stage: 1) Pop Up Book Validation Sheet, Pop Up Book validation sheet is used to obtain data relating to the validity of the Pancasila Pop Up Book. This sheet is given to the validator as a reference in assessing the learning media that has been made by the researcher. In this study, those who act as validators are content feasibility validators, linguistic validators, presentation validators and graphic validators. 2) Student Response Questionnaire Sheet the questionnaire aims to obtain data on student responses to the learning process carried out using the Pancasila Pop up Book learning media. The questionnaire sheet made by the researcher contains questions and statements regarding the Pop up Book that will be filled out by students.

The analysis and validity of the data that will be carried out by researchers in developing Pop Up Books include: 1) Analysis of Pop Up Book Validation Results, The validity of learning resources in the form of 3-dimensional supporting textbooks or Pancasila Pop Up Books is assessed by the validator with the validation sheet provided as reference for the assessment of the validity and practicality of the Pop Up Book. According to Akbar (2013) the steps taken by the researcher in analyzing the data are as follows: a) the researcher prepares the data that has been obtained previously, then analyzes the data. b) After the validator gives a score to the Pop up Book, the researcher will calculate the score for each criterion. c) Guidelines for calculating the maximum score, among others: Validation $(V)=\frac{\text { Total of validasi score }}{\text { Total of maksimum score }} \times 100 \%$, d) The results of the validation are known, the percentage can be matched with the following validation criteria: 
Table 3.6

Validation Result Percentage

\begin{tabular}{|l|l|l|}
\hline No & Score & Validation Criteria \\
\hline 1. & $85 \%-100 \%$ & Very Valid \\
\hline 2. & $69 \%-84 \%$ & Valid \\
\hline 3. & $53 \%-68 \%$ & Quite Valid \\
\hline 4. & $36 \%-52 \%$ & Less Valid \\
\hline 5. & $20 \%-36 \%$ & Very Invalid \\
\hline
\end{tabular}

Source: Subali, at all (2012)

With the number of validation results 69\%, the Pancasila Pop Up Book is declared valid to be used as a learning resource in the form of a learning companion textbook. 2) Analysis of Student Responses. In this study, the analysis of student responses was to provide questionnaires to students after obtaining material using a 3-dimensional companion textbook in the form of the Pancasila Pop up Book. The methods used to measure student responses include: Strongly Agree gets a score of 5, Agree gets a score of 4, Disagree gets a score of 3, Disagree gets a score of 4, and STS Strongly Disagree Agree got a score of 1.

$$
P D \text { Precentage }=\frac{(5 x S S)+(4 x S)+(3 x K S)+(2 x T S)+(1 x S T S)}{(5 x \Sigma) x \text { Total of Studentd }} \times 100 \%
$$

Source: Arikunto, (2019)

Table 3.7

Percentage of Student Responses

Source: Arikunto (2019)

\begin{tabular}{|l|l|l|}
\hline No & Score & Criteria \\
\hline 1. & $81 \%-100 \%$ & Very Good \\
\hline 2. & $61 \%-80 \%$ & Good \\
\hline 3. & $41 \%-60 \%$ & Fairly Good \\
\hline 4. & $21 \%-40 \%$ & Less Good \\
\hline 5. & $0 \%-20 \%$ & Very Poor \\
\hline
\end{tabular}

With the percentage of student responses 61\%, the Pancasila Pop up Book is declared practical and effective to be used as a learning resource in the form of a companion book in the learning process.

\section{RESULTS AND DISCUSSION}

The process of developing the Pancasila Pop up Book based on social values in everyday life for fourth grade elementary school students begins on Friday, July 11, 2021. In the process 
of developing the Pancasila Pop up Book, the researcher uses a 4-D or 4 model. -P which includes four stages, namely Definition, Design stage, Development stage, and Dessemination stage from Thiagarajan and then modified into three stages namely Definition, Design stage, and the Development stage (Develop).

At the definition stage, it is divided into 5 stages, namely: (1) Front End Analysis, front end analysis begins with analyzing the curriculum applied by the school, the curriculum applied is the K13 curriculum. After analyzing the curriculum then identifying problems that occur during the learning process according to what has been described in the background. Because this study focuses on Pancasila material, the researcher looks at the Core Competencies (KI) and Basic Competencies (KD) contained in the fourth grade Pancasila learning. (2) Student Analysis, at this stage of student analysis, researchers conducted interviews with fourth grade teachers at MI Al-Islam 1 Pantenan to find out what problems occurred during the learning process. From the results of interviews, researchers obtained information that fourth grade students still have difficulty understanding the meaning of the Pancasila precepts symbol, students also still have difficulty in distinguishing the application of one precepts from other precepts in daily life, besides that students often feel bored and tend to be unmotivated. In participating in learning due to the limitations of interesting learning resources, students listen to more explanations from the teacher so that students' understanding of the material provided is less evenly distributed and gets bored more quickly in participating in learning on Pancasila material. (3) Material Analysis, the activities carried out at the material analysis stage aim to identify the parts or materials used by researchers in the process of developing learning resources. The material used by the researcher is Pancasila which is contained in the Civics subject on theme 5 "My Heroes". This material analysis phase refers to the curriculum used by schools and is adapted to the KI and KD material for Pancasila. (4) Task Analysis, at the task analysis stage refers to the previous analysis, namely material analysis. This stage is carried out to determine the tasks given to students according to the material used in the study. Making assignments for students refers to the cognitive indicators that have been determined in the Learning Implementation Plan. (5) Planning of Learning Objectives. The planning stage of learning objectives is the last process of the Defining stage. The purpose of this stage is to determine the targets that will be achieved by students in learning activities, with this goal being the basis for preparing learning resources. Planning of learning objectives is the result of the elaboration of indicators that are adjusted to the Basic Competencies that have been determined in the Learning Implementation Plan.

The planning stage is divided into 3 stages, namely: (1) Selection of Learning Resources (Media Selection). At this stage of selecting learning resources, the researcher selects learning resources that will be developed as materials to accompany the learning implementation process. The learning resource chosen by the researcher is the Pancasila Pop Up Book using a 3-dimensional technique so that it can be seen from various points of view. The selection of 
learning resources is based on student analysis, material analysis, task analysis and planning of learning objectives that have been carried out previously. (2) Format Selection, In selecting the print specifications and the size of the Pop Up Book to be produced, the A4 size will be produced. Then for the selection of paper as the main material for the printed results, the researchers used art paper measuring 260 gsm because the process of making Pop Up Books requires paper that is a little stiff so that when the book is opened it will not change the shape of the parts that will appear. Additional materials used to complement the main ingredients use art paper measuring $120 \mathrm{gsm}, 230 \mathrm{gsm}$, and vinyl stickers. Then the results of all the prints that have been assembled will be bound using a hard cover. The format selection stage is also used to compile the Pop Up Book validation sheet which is given to the validator to measure the validity of the Pop Up Book developed. (3) Initial Pop Up Book Plan. At this stage, the aim is to design the Pancasila Pop Up Book according to a predetermined concept. The steps in the process of making a Pop Up Book, among others: a) Creating a background design for each page that is the content of the Pop Up Book using Corel Draw X7 software, then adjusted to a predetermined theme.

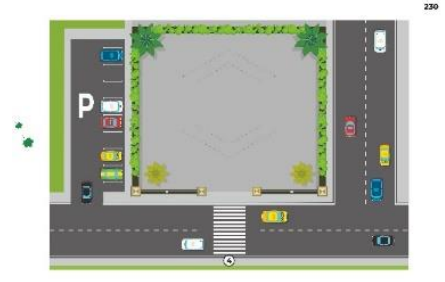

Picture 4.1 Page Background of Pop up Book

b) Making nets or sketches of objects that will be generated in the Pop up Book section, then the sketch is redesigned to resemble the desired object.

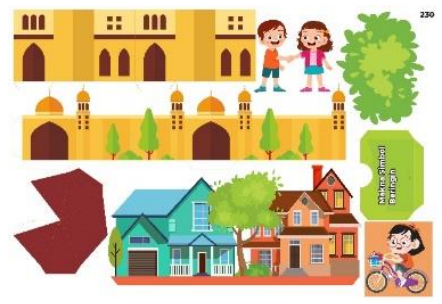

Picture 4.2 Object Sketch of Pop up Book

c) Make additional components on each page that are used as space for explanations of Pancasila material. 


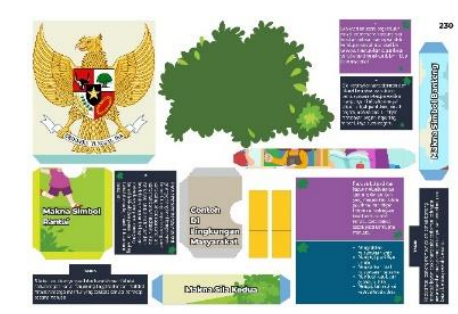

Picture 4.3 Additional Components of Pop up Book

d) Assembling all the parts and additional components that have been printed, then all the parts that have been assembled are finished using a hard cover.

At this development stage, validation will be carried out on Pop Up Book I, if Pop Up Book $\mathrm{I}$ is declared invalid from the validator then it will be repaired again and produce Pop Up Book II, if it is declared valid it will be tested on fourth grade students through a questionnaire. Response to find out the use of the Pop up Book that was developed is feasible or not, if the Pop up Book has not been declared feasible it will be re-tested until the Pancasila Pop up Book is suitable for use in learning. If the Pop up Book has been declared feasible, then the final result of this research is the Pancasila Pop up Book based on social values in everyday life for fourth grade elementary school students.

This study was validated by four validators, namely content feasibility validator, linguistic validator, presentation validator, and graphic validator. The validator of the content feasibility is a teacher who is competent in Pancasila material, namely Suhardi Achwan, S.Pd as a teacher at MI Al-Islam 1 Pantenan. The linguistic validator is a person who is competent in the field of language, namely Afakhrul Masub Bakhtiar, M.Pd, as a PGSD lecturer at the University of Muhammadiyah Gresik. Presentation validator, namely Ashabul Khoiri, S.Pd as a fourth grade teacher at MI Al-Islam 1 Pantenan. The graphic validator is a person who is competent in the field of IT and design, namely Iqnatia Alfiansyah, M.Pd as a PGSD lecturer at the University of Muhammadiyah Gresik. Each validator is given an instrument sheet and also an assessment rubric for the assessment of each aspect of the validation. The results of the validation are in the form of scores, suggestions, and comments on the Pancasila Pop Up Book, then these results are used as material for improvement both in terms of content, language, presentation, and graphics of the Pancasila Pop Up Book. The indicator of the success of developing the Pancasila Pop Up Book refers to Subali, et al (2012), with a validation result of $69 \%$, the Pancasila Pop Up Book can be declared valid and can be tested on students. The results of content feasibility validation, linguistic validation, presentation validation, and graphic validation can be presented in the following table:

Table 4.1

Content Feasibility Validation Results 
UMGCINMATIC: $1^{\text {st }}$ Rethinking Education during Covid-19 Era: Challange and Innovation Volume 1 No 2

\begin{tabular}{|l|l|l|}
\hline No & Aspect & Score \\
\hline 1. & Material Compatibility with KI and KD & \\
\hline & a. Completeness of learning materials & 4 \\
\cline { 2 - 3 } & b. Depth of learning material & 3 \\
\hline 2. & Material Accuracy & \\
\hline & a. Concept Accuracy & 5 \\
\hline 3. & Learning Support Materials & \\
\hline \multicolumn{2}{|l|}{ a. Compatibility of example with material } & 5 \\
\cline { 2 - 3 } & b. Literacy Empowerment & 5 \\
\hline \multicolumn{2}{|l|}{ Total Score } & 24 \\
\hline \multicolumn{2}{|l|}{ Precentage } & 96 \\
\hline
\end{tabular}

Based on the validation results in Table 4.1 above, it can be explained that the content feasibility validation process obtained a score of 24 and the percentage obtained from the total score was $96 \%$. The results of the percentage validation of the feasibility of the contents of the Pancasila Pop Up Book can be calculated as follows:

$$
\begin{aligned}
\text { Validation }(V) & =\frac{\text { Total Validasi Score }}{\text { Maximum Score }} \times 100 \% \\
& =\frac{24}{25} \times 100=96 \%
\end{aligned}
$$

Table 4.1

Language Validation Results

\begin{tabular}{|l|l|l|}
\hline No & Aspect & Score \\
\hline 1. & Conformity with Indonesian Language Rules & \\
\hline & a. Correct word writing & 5 \\
\cline { 2 - 3 } & b. The accuracy of sentence structure & 4 \\
\cline { 2 - 3 } c. Sentence effectiveness & 5 \\
\hline 2. & Readability & 5 \\
\hline \multicolumn{2}{|c|}{ a. Conformity with intellectual development } & 19 \\
\hline Total Score & 95 \\
\hline \multicolumn{2}{l}{ Percentage } & \\
\hline
\end{tabular}

Based on the validation results in Table 4.2 above, it can be explained that the linguistic validation process obtained a score of 19 and the percentage obtained from the total score was 95\%. The results of the percentage of linguistic validation in the Pancasila Pop Up Book can be calculated as follows:

$$
\begin{aligned}
\text { Validation }(V) & =\frac{\text { Total Validasi Score }}{\text { Maximum Score }} \times 100 \% \\
& =\frac{19}{20} \times 100=95 \%
\end{aligned}
$$


Tabel 4.2

Presentation Validation Results

\begin{tabular}{|l|l|l|}
\hline No & Aspect & Score \\
\hline 1. & Presentation Technique & \\
\hline & a. Consistency, coherence, and understanding & 5 \\
\hline 2. & Presentation of learning & \\
\hline & a. Oriented to students (Student Centered) & 5 \\
\cline { 2 - 3 } & b. Encourages curiosity and critical thinking & 4 \\
\hline 3. & Completeness of Presentation & 5 \\
\hline \multicolumn{2}{|c|}{ a. Preface and table of contents section } & 5 \\
\cline { 2 - 3 } & b. Contents & 24 \\
\hline Total Score & 96 \\
\hline Percentage & \\
\hline
\end{tabular}

Based on the validation results in Table 4.3 above, it can be explained that the content feasibility validation process obtained a score of 24 and the percentage obtained from the total score was $96 \%$. The results of the percentage validation of the feasibility of the contents of the Pancasila Pop Up Book can be calculated as follows:

$$
\begin{aligned}
\text { Validation }(V) & =\frac{\text { Total Validasi Score }}{\text { Maximum Score }} \times 100 \% \\
& =\frac{24}{25} \times 100=96 \%
\end{aligned}
$$

Table 4.3

Graphics Validation Results

\begin{tabular}{|l|l|l|}
\hline No & Aspect & Score \\
\hline 1. & Pop Up Book Print Material & \\
\hline & a. Pop Up Book Print Material & 5 \\
\hline 2. & Pop Up Book cover design & \\
\hline & a. Pop Up Book cover illustration & 4 \\
\hline 3. & Pop Up Book content design & \\
\hline \multicolumn{2}{|c|}{ a. Pop Up Book layout Illustration of contents of Pop Up Book } & 4 \\
\hline & a. Pop Up Book Print & 5 \\
\hline 4. & Mold Quality & 3 \\
\hline 5. & Binding quality & \\
\hline \multicolumn{2}{|c|}{ Binding of Pop Up Book } & 4 \\
\hline \multicolumn{2}{|l|}{ Total Score } & 25 \\
\hline Percentage & 83,3 \\
\hline
\end{tabular}

Based on the validation results in Table 4.4 above, it can be explained that the content feasibility validation process obtained a score of 25 and the percentage obtained from the total score was $83.3 \%$. The results of the percentage validation of the feasibility of the contents of the Pancasila Pop Up Book can be calculated as follows: 


$$
\begin{aligned}
\text { Validation }(V) & =\frac{\text { Total Validasi Score }}{\text { Maximum Score }} \times 100 \% \\
= & \frac{25}{30} \times 100=83,3 \%
\end{aligned}
$$

The average percentage obtained from the validation results of the Pancasila Pop Up Book by the validator of the feasibility of content, language, presentation, and graphics obtained a score of $92.5 \%$, with very valid criteria. So that the Pancasila Pop Up Book deserves to be tested on fourth grade students at MI Al-Islam 1 Pantenan.

In addition to validating, to find out the Pancasila Pop Up Book is good/appropriate to use for students, researchers analyzed students using a response questionnaire in the Pancasila Pop Up Book learning. The indicator of good/appropriate use of the Pancasila Pop Up Book refers to Arikunto (2019) with a percentage result of $61 \%$ which indicates that the Pancasila Pop Up Book is practical and effective to use for students. The following are the results of the student response questionnaires:

Table 4.5

\begin{tabular}{|c|c|c|c|c|c|c|c|}
\hline \multirow{2}{*}{ assessment indicators } & \multirow{2}{*}{ Statement } & \multicolumn{6}{|l|}{ Score } \\
\hline & & PD1 & PD2 & PD3 & PD4 & PD5 & PD6 \\
\hline \multirow[t]{4}{*}{ A. Interests } & $\begin{array}{l}\text { 1. } \text { This Pancasila Pop Up } \\
\text { Book Display is } \\
\text { interesting }\end{array}$ & SS & SS & SS & SS & SS & SS \\
\hline & $\begin{array}{ll}\text { 2. } & \text { I enjoy learning by } \\
\text { using Pop Up Book } \\
\text { Pancasila }\end{array}$ & SS & SS & SS & SS & SS & SS \\
\hline & $\begin{array}{ll}\text { 3. } & \text { Images and forms of } \\
\text { Pop Ups on the } \\
\text { Pancasila Pop Up Book } \\
\text { various }\end{array}$ & SS & SS & SS & SS & SS & SS \\
\hline & $\begin{array}{l}\text { 4. Learning with Pop Up } \\
\text { Book Pancasila is not } \\
\text { boring }\end{array}$ & SS & SS & SS & SS & SS & SS \\
\hline \multirow[t]{4}{*}{ B. Material } & $\begin{array}{l}\text { 1. The material presented } \\
\text { in the Pancasila Pop Up } \\
\text { Book is easy to } \\
\text { understand }\end{array}$ & SS & SS & SS & $\mathrm{S}$ & SS & $\mathrm{S}$ \\
\hline & $\begin{array}{l}\text { 2. The presentation of the } \\
\text { material in the } \\
\text { Pancasila Pop Up Book } \\
\text { is very coherent }\end{array}$ & SS & SS & SS & SS & SS & SS \\
\hline & $\begin{array}{l}\text { 3. In the Pancasila Pop Up } \\
\text { Book there are } \\
\text { examples so that it is } \\
\text { easy to distinguish } \\
\text { examples of one } \\
\text { precept from another } \\
\end{array}$ & SS & SS & SS & SS & SS & SS \\
\hline & 4. The material is placed & SS & SS & SS & SS & SS & SS \\
\hline
\end{tabular}

Student Response Questionnaire 
UMGCINMATIC: $1^{\text {st }}$ Rethinking Education during Covid-19 Era: Challange and Innovation Volume 1 No 2

\begin{tabular}{|c|c|c|c|c|c|c|c|c|}
\hline & & $\begin{array}{l}\text { in various forms of Pop } \\
\text { UP so that it is } \\
\text { interesting to read }\end{array}$ & & & & & & \\
\hline \multirow[t]{2}{*}{ C. Language } & 1. & $\begin{array}{l}\text { The presentation of } \\
\text { sentences and } \\
\text { paragraphs in the } \\
\text { Pancasila Pop Up Book } \\
\text { is clear and easy to } \\
\text { understand }\end{array}$ & S & $\mathrm{S}$ & SS & SS & $\mathrm{S}$ & SS \\
\hline & & $\begin{array}{l}\text { The letters/fonts used } \\
\text { are very diverse and } \\
\text { easy to read }\end{array}$ & $\mathrm{S}$ & $\mathrm{S}$ & SS & SS & SS & $\mathrm{S}$ \\
\hline \multicolumn{3}{|l|}{ Description } & \multicolumn{6}{|c|}{$\mathrm{SS}=52, \mathrm{~S}=8, \mathrm{KS}=0, \mathrm{TS}=0, \mathrm{STS}=0$} \\
\hline Persentage & & & 97, & & & & & \\
\hline
\end{tabular}

Based on the validation results in Table 4.5 above, it can be explained that the student response questionnaire obtained a percentage of $97.3 \%$. The results of the percentage of student response questionnaires in the Pancasila Pop Up Book learning can be calculated as follows:

$$
\begin{aligned}
& P D \text { Precentage }=\frac{(5 x S S)+(4 x S)+(3 x K S)+(2 x T S)+(1 x S T S)}{(5 x \Sigma) \times \text { Total of Studentd }} \times 100 \% \\
= & \frac{(5 x 52)+(4 x 8)+(3 x 0)+(2 x 0)+(1 \times 0)}{(5 x 10) \times 6} \times 100 \% \\
= & \frac{260+32}{300} \times 100 \% \\
= & \frac{293}{300} \times 100 \% \\
= & 97,6 \%
\end{aligned}
$$

From the results of the student response questionnaire above, the criteria are good, namely $97.3 \%$ which shows that the Pancasila Pop Up Book is practical and also effectively used as a learning resource in the form of a companion book for fourth grade students at MI AlIslam 1 Pantenan.

The percentage obtained from the validation results of the Pancasila Pop Up Book by the content feasibility validator obtained a score of $96 \%$, with very valid criteria. The results of the validation by the linguistic validator obtained a score of $95 \%$, with very valid criteria. The results of the validation by the presentation validator get a score of $96 \%$, with very valid criteria. While the results of the validation by the graphic validator get a score of $83.3 \%$, with valid criteria. The average percentage of the results of the validation of the Pancasila Pop Up Book by the validator of the feasibility of content, language, presentation, and graphics obtained a score of $92.5 \%$, with very valid criteria. So that the Pancasila Pop Up Book deserves to be tested on fourth grade students at MI Al-Islam 1 Pantenan. Meanwhile, to find out the Pop Up Book Pancasila is practical and effective to use for students, the researcher analyzed the students using a response questionnaire in learning the Pop Up Book Pancasila. The good/appropriate indicator of the use of the Pancasila Pop Up Book refers to Arikunto (2019) with a percentage result of $61 \%$ which indicates that the Pancasila Pop Up Book is practical and also effectively used for students. The results of the questionnaire responses to the six students obtained a score of $97.3 \%$ 
into the very good/decent category.

The Pancasila Pop Up Book has advantages, including: (1) The Pancasila Pop Up Book has a bright animative design by showing objects that resemble the content of the material, so that it can increase students' reading motivation and give a real impression on the material provided. (2) The Pancasila Pop Up Book has 3-dimensional (3D) properties or has a volume that can be seen from various directions, making it more interesting when used. (3) The Pancasila Pop Up Book contains examples of social values in Pancasila, making it easier for students to understand the material presented. (4) The Pancasila Pop Up Book is flexible, meaning it can be used anywhere and anytime when needed. (5) The Pancasila Pop Up Book can be used as a learning resource in the form of a learning companion book. The Pancasila Pop Up Book also has several shortcomings, including: (1) The Pancasila Pop Up Book object is difficult to emerge because of the irregular shape of the object. (2) The cost of making Pop Up Book Pancasila is relatively expensive. (3) In some Pop Up Book materials can be taken or not attached to the pop up so it is easy to lose.

\section{CONCLUSIONS AND SUGGESTIONS}

Based on the results of the research on the development of the Pancasila Pop Up Book, it can be concluded that the process of developing the Pancasila Pop Up Book was carried out in the fourth grade of elementary school at MI Al-Islam 1 Pantenan with a total of 6 students, namely 3 male students and 3 female students. . The process of developing the Pancasila Pop Up Book using the 4-D model from Thiagarajan includes four stages, namely Definition, Design stage, Development stage, and Dessemination stage which is then modified into three stages, namely Definition (Definition). Define), the Planning stage (Design), and the Development stage (Develop).

In the research on the development of the Pancasila Pop Up Book using four validators, namely the content feasibility validator, the linguistic validator, the presentation validator, and the graphic validator using the percentage validity indicator of $69 \%$. The validation of the Pancasila Pop Up Book by the content feasibility validator obtained a score of $96 \%$, with very valid criteria. The validation of the Pancasila Pop Up Book by the linguistic validator obtained a score of $95 \%$, with very valid criteria. The validation of the Pancasila Pop Up Book by the presentation validator obtained a score of $96 \%$, with very valid criteria. And the validation of the Pancasila Pop Up Book by the graphic validator obtained a score of $83.3 \%$, which also shows that the Pancasila Pop Up Book is included in the valid criteria. From the four validator scores, an average score of $92.5 \%$ can be taken. So it can be concluded that the Pancasila Pop Up Book in terms of the feasibility of content, language, presentation, and graphics, has very valid criteria and can be tested.

Analysis of student responses in this study used a response questionnaire, using a response percentage of $61 \%$. The results of the analysis of student responses using anget 
responses get a score of $97.3 \%$ into the very good/decent category. So it can be concluded that the Pancasila Pop Up Book based on social values in everyday life in fourth grade elementary school students can be said to be practical and also effective to be used as a tool or learning resource for students in the learning process.

Based on the results of the discussion and conclusions, the researchers can provide several suggestions, including: For teachers/educators to use the Pancasila Pop Up Book as an alternative in delivering Pancasila material and make learning resources in the form of companion textbooks to complement the learning process. For further research to make this research as a reference to produce learning resources that are more interesting, creative, and innovative in learning activities. 


\section{REFERENCES}

Akbar, S. (2013). Instrumen Perangkat Pembelajaran. Bandung: PT Remaja Rosdakarya.

Anas, M., Damayanti, G., Rahmawan, T. I., \& dkk. (2017). Kewarganegaraan. Malang: Madani.

Arikunto, S. (2019). Prosedur Penelitian. Jakarta: Rineka Cipta.

Asmaroini, A. P. (2017). Menjaga Eksistensi Pancasila dan Penerapannya Bagi Masyarakat di Era Globalisasi. Jurnal Pancasila dan Kewarganegaraan, Vo. 2 No 1, e-ISSN 2527-7057, p-ISSN 2545-2683.

Burhanudin, S. (2021, Maret 10). Nilai Sosial. Retrieved from Studio Belajar: https://www.studiobelajar.com/nilai-sosial/

Effendy, S., Kustiana, A., Mulyono, D., \& dkk. (2018). Pendidikan Pancasila. Bandung: PT Refika Aditama.

Fitri, Anisa, N., \& Karmila. (2018). Pengembangan Media Pop up Book Kubus dan Balok untuk Siswa Kelas V Sekolah Dasar. Jurnal Ilmiah Pendidikan Guru Sekolah Dasar, Vol. 5 No. 4 , 226-239.

Kompri. (2015). Manajemen Pendidikan. Yogyakarta: Ar-Ruzz Media.

Najahah, I. (2016). Perencanaan Buku Pop up Sebagai Media Pembelajaran Tentang Rumah dan Pakaian Adat Nusantara di Jawa. Jurnal Pendidikan Seni Rupa, Vol. 04 No 03, 494-501.

Ningtiyas, T. W., Setyosari, P., \& Praherdiono, H. (2019). Pengembangan Media Pop Up Book untuk Mata Pembelajaran IPA Bab Siklus Air dan Peristiwa Alam sebagai Penguatan Kognitif Siswa. Jurnal Kajian Teknologi Pendidikan (JKTP), Vol 2 No 2, e-ISSN 26158787, 115-120.

Rahmatilah, S., Hidayat, S., \& Apriliya, S. (2017). Media Buku Pop Up untuk Pembelajaran Bahasa Indonesia di Kelas Rendah. Jurnal Ilmiah Pendidikan Guru Sekolah Dasar, Vol. 4 No. 1, 139-148.

Siregar, A., \& Rahmah, E. (2016). Model Pop up Book Keluarga untuk Mempercepat Kemampuan Membaca Anak Kelas Rendah Sekolah Dasar. Ilmu Informasi Perpustakaan dan Kearsipan, 10-21.

Trianto. (2015). Model Pembelajaran Terpadu. Jakarta: PT Bumi Aksara. 